\title{
A REVIEW OF THE AMERICAN SPECIES OF THE GENUS
} PALLOPTERA.

\author{
By Charles W. Johnson, \\ Boston Society of Natural History, Boston, Mass.
}

In a recent study of the species of Palloptera, including the type of $P$. jucunda Loew, in the Museum of Comparative Zoölogy, it seemed that some discrepancies existed that should be corrected. Prior to Dr. A. L. Melander's paper ${ }^{1}$ no figures accompanied the original descriptions, and this may account for some of the errors. A comparison of the figure of the wing of $P$. jucunda by Melander with the type shows a marked difference (although the series of $P$. jucunda shows some variation) and is apt to be misleading, especially since there is a much larger species having practically the same wing pattern as that figured for $P$. jucunda. The wing figured as $P$. jucunda in Williston's Manual of North American Diptera, 3d edition, page 80 , is $P$. superba. I have been unable to find an American species agreeing with the European $P$. arcuata Meig. It was determined by Coquillett and recorded from Mt. Washington, N. H., by Mrs. Annie T. Slosson, but none of the specimens I have collected there and at Mt. Desert, Me., agree with that species. Submitting a sketch of the wing of a specimen taken at Base Station, Mt. Washington, to Mrs. Slossom, she writes: "I have looked up the unique specimen of $P$. arcuata. It is in poor condition, abdomen missing, but wings perfect. They are exactly like your figure, clouded at the tip, not extending along the costa."

\section{TABLE OF Species.}

1. Cross-veins not bordered with brown, auxillary and first vein, and apex of wing brownish; thorax grayish-pollinose.

terminalis Loew.

Only the posterior cross-vein and tip of the wing bordered with brown; thorax yellow (Fig. 1)....... subarcuata sp. nov. Both of the cross-veins, tip of the wing, and costal margin partly or entirely bordered with brown............2

1 Psyche, 1913, Vol. 20, p. 80, pl. 3, figs. 16-21. 
2. Costal margin interrupted and the brown clouding of the anterior cross-vein not connected.................

Costal margin broad and continuous, covering the anterior cross-

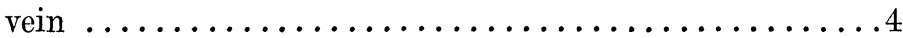

3. First and auxillary veins brown only at the costa, leaving the base and middle of the costal margin hyaline; length $4 \mathrm{~mm}$. (Fig. 2).................... jucunda Loew First and auxillary veins included in the brown costal margin; first and basal half of the second costal cell yellow; length $7 \mathrm{~mm}$. (Fig 3)................... albertensis sp. nov.

4. Thorax and abdomen largely cinerous-pruinose; abdominal segments setose; four rows of acrosticals; wing pattern resembling similis; length $3.5 \mathrm{~mm} . \ldots \ldots \ldots$..... setosa Mel. Thorax and abdomen shining yellow, brown of the posterior cross-vein not connected with the costal margin; abdominal segments narrowly margined with black, setæ small; length $6 \mathrm{~mm}$. (Fig. 4)................... similis Johns.

Thorax and abdomen yellow, subshining; thorax with two pruinose subdorsal stripes; brown of the posterior cross-vein connected with the costal margin; abdominal segments with large marginal setæ, arising from black spots. . superba Lœw.
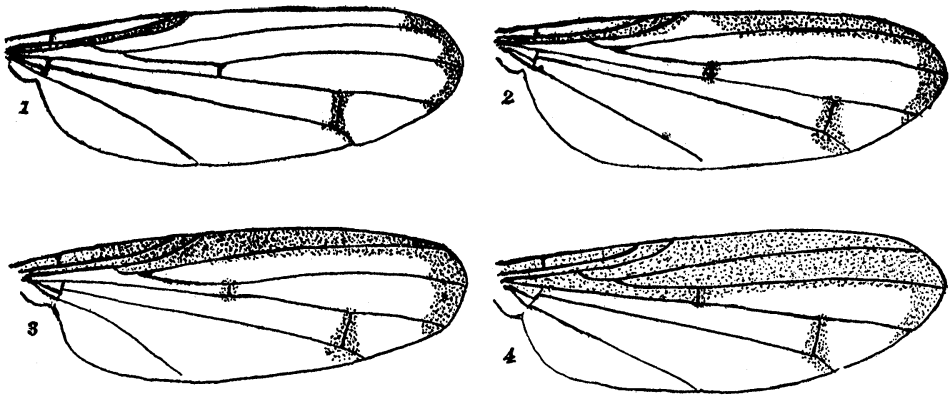

Fig. 1. Wings of Palloptera.

Palloptera subarcuata sp. nov. (Fig. 1).

P. arcuata Slosson, Ent. News, 1895, vol. 6, p. 7 (determined by Coquillett) and Johnson, Psyche, 1910, vol. 1\%, p. 233 (not Meigen).

Male. Front yellow opaque, vertical margin, frontal orbits, face 
and lower half of the occiput whitish, ocellar triangle black, first and second joints of the antennæ yellow, third brownish, arista brown and pubescent. Thorax and scutellum yellow, shining, with fine brown hairs, one prominent dorso-central and four large marginal scutellar bristles. Abdomen yellow, third, fourth, and fifth segments brown. Legs including the coxæ light yellow, halteres yellow. Wings hyaline, first veins but slightly clouded, tip of wing and posterior cross-vein broadly clouded with brown. Length, male $4.5 \mathrm{~mm}$., female, including ovipositor, $5 \mathrm{~mm}$.

Seven specimens. Holotype, Bar Harbor, Me., Aug. 10, 1920 (C. W. J.). Allotype, Northeast Harbor, Me., July 1, 1909 (Dr. C. S. Minot), and two paratypes, Bar Harbor, Aug. 15, and Base Station, Mt. Washington, N. H., Aug. 15, 1916 (C. W. J.), in the collection of the Boston Society of Natural History. Paratypes are also in the Museum of Comparative Zoölogy, U. S.National Museum, Mrs. Slosson's and the author's collections.

\section{Palloptera jucunda Loew (Fig. 2).}

In addition to the type locality, Sitka, Alaska, and the localities recorded by Melander, I have specimens before me from Parroquet Island, Labrador, July 21, $188 \%$ (S. Henshaw), Mus. Comp. Zoöl.; Midvale, Montana, Aug. 25 (C. E. Brown) ; Logan, Utah, Sept. 1915 (H. B. Hagan). Cranbrook, B. C., Sept. 12 (C. Garrett).

Palloptera albertensis sp. nov. (Fig. 3).

Front dark yellow, opaque, orbits, face and occiput light yellow, antennæ yellow (third joint wanting). Thorax and scutellum yellow, subshining, with macrochætæ similar to $P$. jucunda. Abdomen yellow, with a narrow black dorsal line expanding toward the top, ovipositor brown, forming about two-fifths the length of the entire abdomen. Legs and halteres yellow. Wings, near the end of the first vein and base of the costal margin, yellowish. Length, including the ovipostor, $7 \mathrm{~mm}$.

One specimen, Calgary, Alberta, Canada, collected by Mr. Owen Bryant.

The larger size, black dorsal line on the abdomen, and heavier 
markings on the wings, separate this from $P$. jucunda. The wing figured by Melander resembles this more than it does the typical jucunda, yet there are variations of the latter in which the wing markings approach this species. The brown costal margin has a spot of slightly lighter shade just beyond the tip of the first vein, scarcely noticeable to the naked eye. In jucunda this spot in the costal margin is usually much larger and hyaline.

\section{Palloptera similis Johnson (Fig. 4).}

Since describing this species from Fort Kent, Me. (Psyche, 1910, vol. 17 , p. 233), I have taken it on the carriage road, Mt. Washington, N. H., at about 2,500 feet, July 24, 1915. 'The wing pattern resembles that of $P$. setosa Melander. 

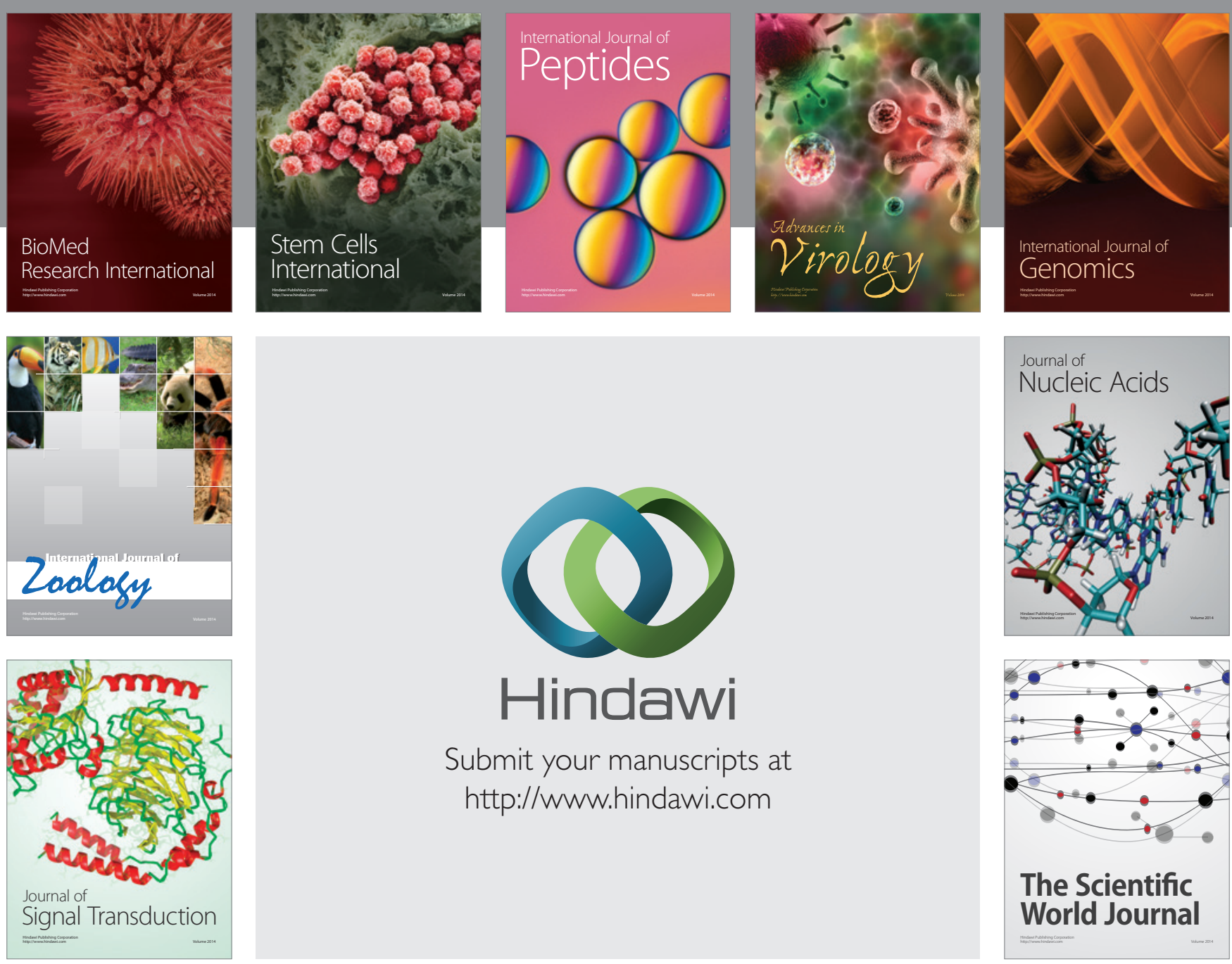

Submit your manuscripts at

http://www.hindawi.com
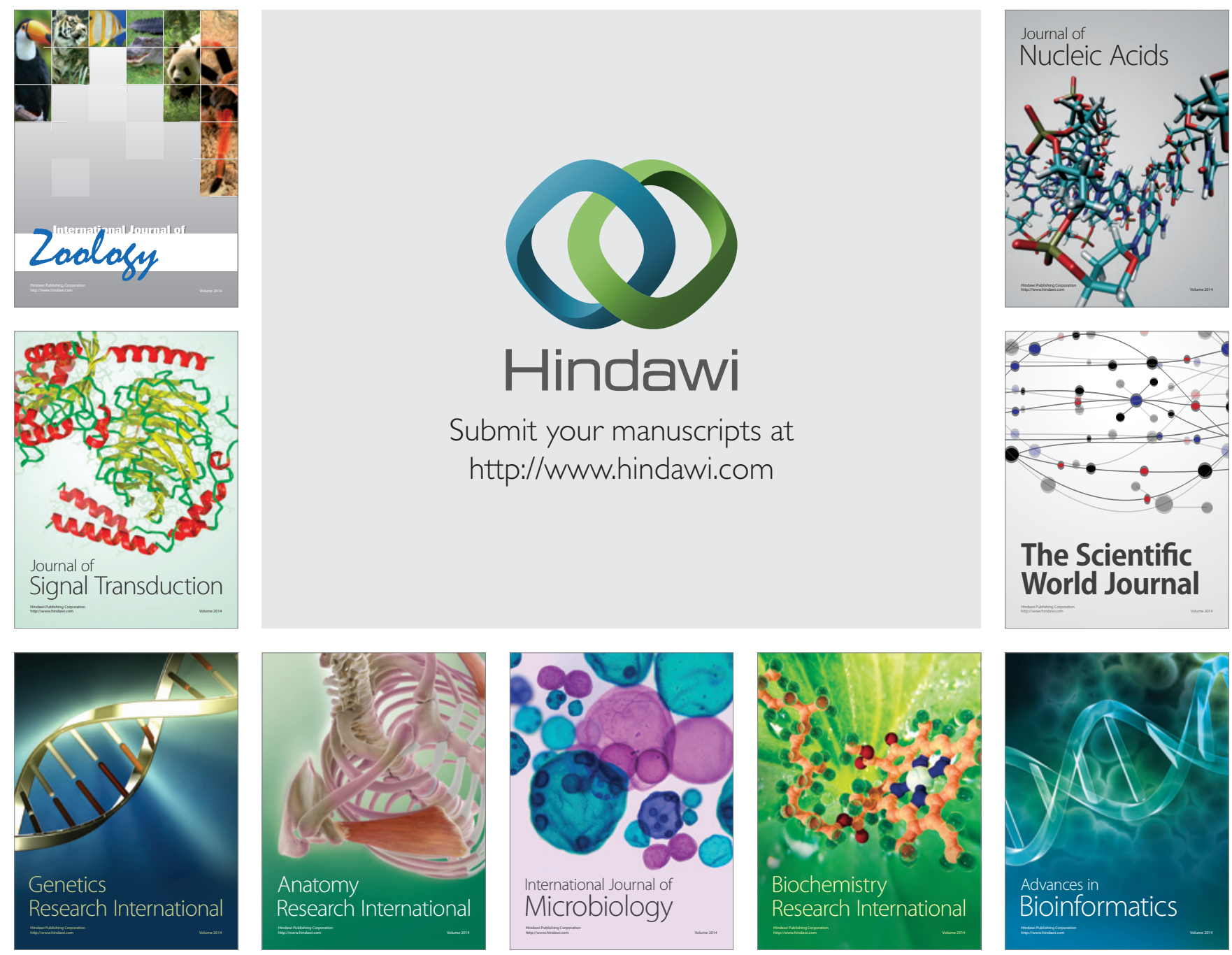

The Scientific World Journal
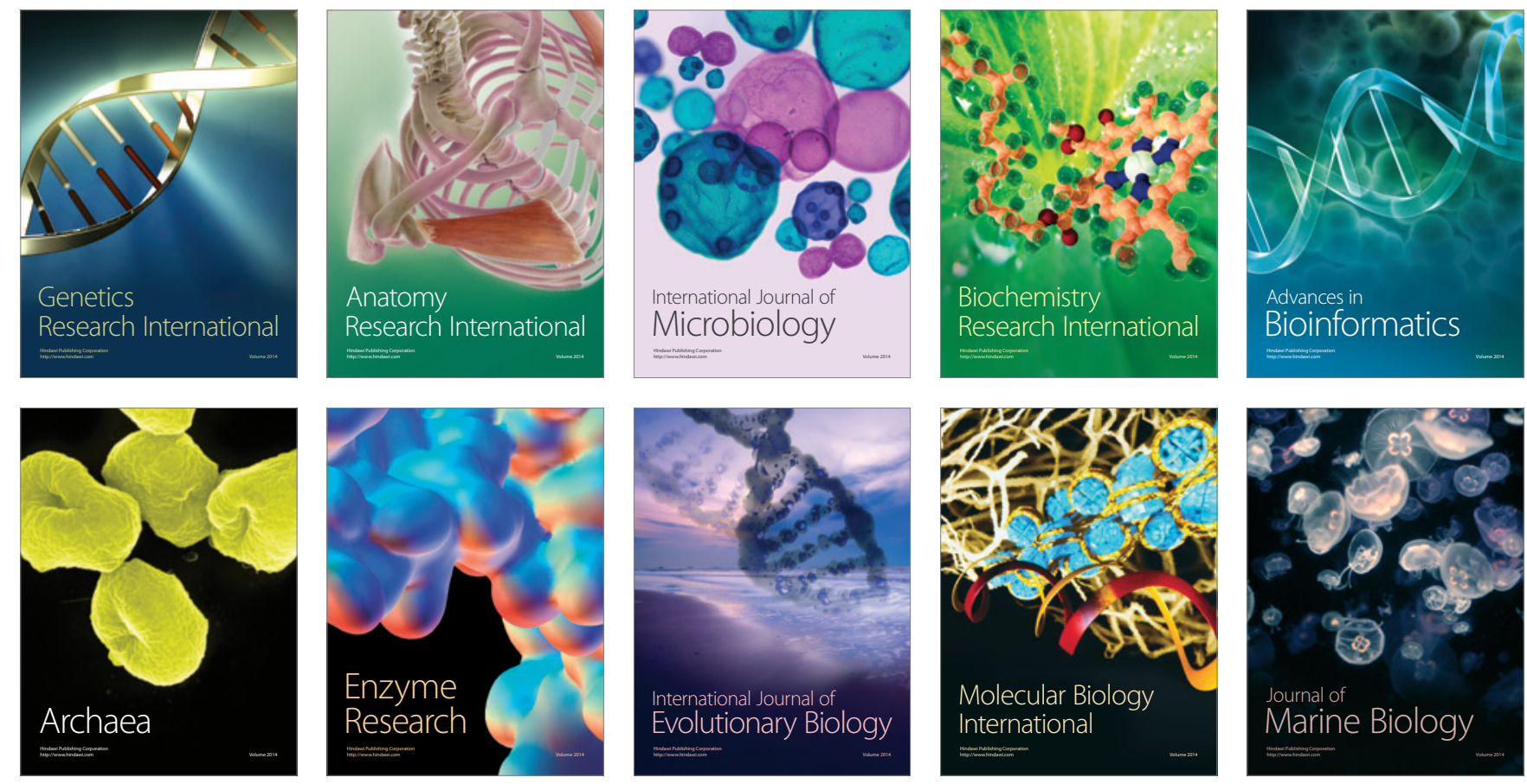